\title{
Political and scientific support for the establishment of the Veterinary School in Lwów
}

\section{KEYWORDS}

education, Szkoła Weterynarii, Akademia Medycyny Weterynaryjnej, Lviv

\begin{abstract}
Dzikowski Andrzej, Political and scientific support for the establishment of the Veterinary School in Lwów. Culture - Society - Education no. 1(17) 2020, Poznań 2020, pp.117-126, Adam Mickiewicz University Press. ISSN 2300-0422. DOI 10.14746/kse.2020.17.5.
\end{abstract}

Establishment of the veterinary university in Lwów would not be possible without the political support of Galician authorities, i.a. A. Potocki and S. Zamoyski, Galician and Viennese MPs, and professors A. Biesiadecki, P. Seifmann, H. Kadyi, and J. Szpilman, who performed repeated and uninterrupted activities of both official and unofficial character. Their contribution, postulates, commitment, and work undertaken, had overcame the resistance of central governmental powers. Creation of the Lwów veterinary academic school enabled training not only Polish veterinarians in their mother tongue, but was also an opportunity for students from other Slavic states. The aim of the work is to show the role of political and administrative supporters of the illustrious idea of the Veterinary School, and then lead to its elevation to the Academy.

\section{Introduction}

The efforts of political lobbyists and scientific supporters of veterinary higher education in Polish resulted in the creation and development of the Imperial and

* ORCID https://orcid.org/0000-0002-3223-7542. 
Royal Veterinary School in Lwów [c. k. Szkoła weterynaryi we Lwowie]. The paper covers the period leading to the establishment of the school as well as its initial operation. Outside the scope of the present work remain: the 'prehistory' of veterinary education in Lwów at the end of the $18^{\text {th }}$ century, the period of its reform and transformation into the Veterinary Academy [c. k. Akademia weterynaryi, Akademia weterynarii, Tierärztliche Hochschule]; as well as the end of this era, marked by the replacement of Austro-Hungarian and Galician law with Polish law, and the renaming of the school as the Academy of Veterinary Medicine [Akademia Medycyny Weterynaryjnej].

Official and unofficial written sources concerning legal sources, administrative documents, archival material, and memoir accounts were analyzed together with the current and $19^{\text {th }}$ century literature. Numerous inaccuracies and misconceptions were revealed in the current literature. In addition to presenting important influential individuals and their efforts, the aim of the work is to eliminate these errors. Efforts of political and scientific lobbyists will be presented together with their biographical data.

\section{Politics and political support}

What distinguishes administrative or scientific activities from political ones, is their transparency and, above of all, procedures. Administrative decisions or decrees are adopted in a specific manner, as a result of the actions of a specific body, which within its competence can only and as much as legal norms allow in case of public administration. Scientific research is also conducted in a specific manner, as a result of a well-based, methodologic and ethical process. Political influence, on the other hand, is not limited by such factors, and is often exerted through courtesy visits, family sympathies and antipathies, talks behind the scenes, informal transactions, or even do ut des, flattery and bribes.

It should be noted that being a political supporter or a lobbyist was often connected with a given person's role in a public legislative and administrative bodies. Temporal and spiritual offices, as well as behind-the-scenes political influence, were at that time an exclusive domain of men of noble social status. But even nobility was often not enough. To impose certain views and ideas, it was necessary to belong to the aristocracy in terms of both the title and property. Many of the noblemen mentioned in this article were closely related, they were the elite of the Galician society. Nevertheless, one should remember that the titles of princes or counts among Polish aristocracy were of Austrian, Russian or German origin. 
Apart from magnates, a firm group of supporters of establishing a Polish veterinary school were local politicians, often of a noble background in case of the Galician parliament or local self-government. Municipal authorities and veterinary professors recruited from the bourgeoisie.

The shape of academic studies in the $19^{\text {th }}$ century Habsburg empire was determined not by the free scientific development or researchers' curiosity. It was subject to the state policy, in case of the Viennese Veterinary Academy - military policy (Bujko, Baran, 2015; Sroka, 1999). This influence was also visible in the new Galician school (Sroka, 1999). The aim of all activities was to favor the central authorities, including the key player of Austria-Hungary - the monarch himself. Francis Joseph I, as the King of Galicia and Lodomeria and the Grand Duke of Cracow, could have, and had wanted to, exert a direct influence on functioning of his empire, including veterinary education. He was one of the most long-lived monarchs in history, born 1830, ruled since 1848, died 1916. Despite the uneasy consent for democratization of public life, and the federal, dualistic concept of the state - His Imperial and Royal Apostolic Majesty was still a disposer of favors and disgrace.

To exert an influence on the emperor, it was crucial to gain recognition among the Viennese central authorities and the immediate surroundings of the monarch. The interior minister and the minister of religious denominations and education were of key importance. The impact could have been exerted, above all, by politicians exercising the highest executive power. Polish counts Agenor Gołuchowski [born 1812, died 1875], and Alfred Józef Potocki [born 1817, died 1889] were Austrian Ministers of Internal Affairs [Gołuchowski in the years 1859-1861, Potocki in the years 1870-1871], Governors of Galicia [Gołuchowski in the years 18491859, 1866-1868 and 1871-1875, Potocki in the years 1875-1883], Viennese and Galician MPs and members of the House of Lords. Potocki was also the Minister of Agriculture, and Galician Marshal.

Although the legislature had limited significance, and low efficiency in the Cisleithania, it was also necessary to convince the members of the central and local diets. Many Galician parliamentarians were simultaneously members of the Viennese Council of State. Polish archbishops and aristocrats seat in the House of Lords. Many noblemen were elected to the House of Deputies. The evidence of this situation is the speech of Apolinary Jaworski of December $9^{\text {th }}, 1875$.

Support from the central authorities would be void without initiative proceeding from the ranks. The involvement of local political factors, including the Governorship of Galicia, Executive Department [before the establishment of the AustroHungarian dualist monarchy: Wydział Stanowy, later on: Wydział Krajowy], the 
Diet [Stany Galicyjskie, later on: Sejm Krajowy], and city authorities should be noted. Professors of the Lwów university, together with the medical community, physicians and official veterinarians promoted the idea. Without their repeated efforts, the history of veterinary medicine in Lwów, and in Poland, would have been completely different.

\section{Projects and proposals}

The initial projects were put forward since 1823 (gubernium, 1823; Seifmann, 1886a; Sroka, 1999) by Anton Leopold Buchmüller [Austrian physician], and Joseph Schultes [military chief blacksmith of Württemberg origin]. It should be noted that, contrary to the part of sources and literature (Seifmann, 1886a; Wróblewski et al., 2012), Joseph Schultes was one person, not a couple of gentlemen by the surnames of 'Joseph', and 'Schultes' (Sroka, 1999; odezwa, 1823).

Further projects came from lecturers, Austrian doctors, and veterinarians: Georg Franz Eckel, and Franz Frisch. They were submitted to the Galician States in the first half of the $19^{\text {th }}$ century. The authors assumed the establishment of private [joint-stock company] or public-private, profit-oriented schools (Seifmann, 1886a; Sroka, 1999).

Since 1855, the Galician budget included a special reserve for veterinary education. The 1859 project envisaged the establishment of a horse-forging school with the elements of veterinary, and zootechnical procedures (Seifmann, 1886a; 1886b; Sroka, 1999). This idea obtained administrative, and material support of the Executive Department, and the city executive represented by the mayor Franz [Franciszek] Kröbl [born 1803, died 1869, Austrian clerk and police officer] (Małecki et al., 1896). This project was abandoned. It assumed low costs, but at the same time low-quality education.

The necessity of teaching veterinary medicine in Polish was formally raised for the very first time (dekret 1859). This postulate was not to be withdrawn (Wróblewski et al., 2012). One of the arguments in favor of the Polish language was the fact that higher studies should have been carried on in the very same language as the lower education was (Padura, 2011; sprawozdanie stenograficzne, 1874). More important was, obviously, that this was the only chance for Polish veterinary education during partition times (Seifmann, 1886c).

The Galician Diet adopted on the $19^{\text {th }}$ sitting of the $5^{\text {th }}$ session of its $3^{\text {rd }}$ period, October $14^{\text {th }}, 1874$ a resolution to establish a veterinary university in Lwów (sprawozdanie stenograficzne, 1874; Grodziski, 1993). The date 1871 (Tarczyński, 1990; 
Gamota, 2011), often appearing in the literature instead of 1874, is not confirmed by historical sources. The vote took place at the request of the Executive Department [Wydział Krajowy], whose work, as well as the work of the parliament, was headed by prince Leon Ludwik Sapieha [born 1803, died 1878, was the Galician Marshal, hereditary member of the House of Lords, hero of uprising 1830/1831, founder of the agricultural school in Dublany/Lwów]. The rapporteur was count Stefan Zamoyski [born 1837, died 1899, member of the local governmental bodies, Galician parliament and Viennese House of Lords].

It was decided to bring into being a permanent, public veterinary school as a national Galician institute [zakład krajowy]. Blacksmith vocational school [horse-forging school, Szkoła kucia koni], and animal hospital were to be subunits of the institute. The school was to be launched as early as the school year $1875 / 1876$. The anachronistic demand of the previous projects to create only three academic chairs maintained.

It should be noted that the transcripts of the parliamentary sessions (sprawozdanie stenograficzne 1874) clearly indicate that the idea of establishing a national [Galician in meaning of Polish] veterinary school, with Polish as a lecture language was already fully-formed. The parliamentary discussion and doubts were only of financial nature. The members of the Diet firmly limited the budget of the future institution.

Stefan Zamoyski, together with Kazimierz Grocholski, Paweł Skwarczyński, Ludwik Skrzyński, and Kajetan Agopsowicz defended the project, and the originally-assumed funding (sprawozdanie stenograficzne, 1874). Skwarczyński emphasized the need to protect national wealth of animal breeding. Grocholski shown - on the example of the Dublany school - the need to guarantee high professors' income to attract good specialists to join the new institution, and to ensure the high academical qualifications of its students. Similar statements were made about the blacksmith teachers. He emphasized that the graduates would have the same rights as Viennese veterinarians, and would work all over the Empire and abroad. This opinion was confirmed by Zamoyski. Grocholski and Zamoyski had also recalled that Polish veterinary professors could be found not only in Galicia, but also in parts of the country under Russian, and Prussian occupation. Only Bazyli [Wasyl] Kowalski, the only-one nobleman who spoke Ruthenian, did not agree with the need to establish a veterinary academic school. The backwardness he presented was based on the opinion that there was no need for a university education, and that a secondary school was enough. In the discussion he emphasized financial savings. Zamoyski firmly, and bluntly opposed Kowalski. He affirmed the need of higher, academic veterinary educa- 
tion for the sake of the high quality veterinary services (sprawozdanie stenograficzne, 1874).

The 1874 resolution was replaced by the vote of May $20^{\text {th }}, 1875$ (Seifmann, 1886a; sprawozdanie stenograficzne, 1875). The idea of the school's erection as a solely-Galician institute was abandoned for financial reasons. Partly Galician, partly central financing was assumed. The local Diet called the Viennese government to create the school. The Executive Department was obliged to negotiate with the central authorities. The goals were to establish the school's statute, and to obtain the highest possible subsidies for the launch, and annual operation of the institution.

\section{Establishment and initial organization}

Negotiations were conducted with the Imperial and Royal Ministry of Religious Affairs and Education. Minister Karl von Stremayr was sceptic about the project (reskrypt, 1876; Sroka, 1999). The lack of interest of potential students was assumed. Those fears turned out to be completely misguided, and groundless. Veterinary studies, contrary to horse-forging vocational courses, enjoyed great interest.

The Galician Diet rejected the comments of the Ministry of Religious Affairs and Education on April 25 $5^{\text {th }}, 1876$ (stanowisko, 1876). Ludwik Skrzyński urged administrative bodies to continue their efforts on April 25 ${ }^{\text {th }}$, and August $28^{\text {th }}, 1876$ (Seifmann, 1886b; stanowisko, 1876). Efforts were hold by the Executive Department, headed by count Włodzimierz Ksawery Dzieduszycki (born 1825, died 1899, Lwów and Vienna MP). Dzieduszycki summoned the new Governor count Alfred Potocki (pismo, 1876a), and the Minister of Agriculture count Hieronymus von Colloredo-Mansfeld (pismo, 1876b) to support the efforts for Lwów veterinary college (Seifmann, 1886b; Wróblewski et al., 2012). Governor Potocki, and the members of the $4^{\text {th }}$ period of the Galician Diet, chaired by the Marshal count Ludwik Wodzicki (born 1834, died 1894), were deeply engaged in gaining support. Colloredo-Mansfeld's acceptance is the effect of the joint determination of Galician administration and deputies.

Alfred Potocki was constantly seeking in Vienna for approval of the plans, and funds (sprawozdanie, 1879; allegat, 1880; Seifmann, 1886b; Wróblewski et al., 2012). He tried to gain consent of the government, and of individual ministers (odezwa, 1879; relacja, 1879). Efforts managed to acquire, and deepen the support of other influential individuals at the Imperial and Royal Court, were repeated. The group of Polish employees of the Viennese Ministries: Home Affairs - Maury- 
cy Röll, Agriculture - Wacław Zaleski, and Education - Ludwik Ćwikliński, helped in negotiations (Sroka, 2001).

Political overtures were crowned with success on December $27^{\text {th }}, 1880$. Emperor Francis Joseph I established the Imperial and Royal Veterinary School in Lwów with a horse-forging school, and a veterinary hospital. On September $15^{\text {th }}$, 1881 the scientific staff was appointed. Also these dates are misinformed in the part of the literature (Tarczyński, 1990).

The process of the founding of the school was carried out by the Internal Ministry, acting in consultation with the Ministry of Religious Affairs and Education (reskrypt, 1881a; reskrypt, 1881b; Padura, 2011). These acts confirmed Polish, and academic nature of the new educational institution. Organizational subordination to the Department of Education, and not to the military one, was fixed (Kadyi, 1895). At the turn of $1877 / 1878$, the school's budget was set, thanks to Potocki's engagement.

At Potocki's request, the school's organization was merged by prof. Alfred Biesiadecki [Galician chief physician, born 1839, died 1889]. Biesiadecki's role was also to find Polish researchers, and teachers (Kadyi, 1895; Padura, 2011; Seifmann, 1886b; 1886d). He accomplished this task brilliantly (Kadyi, 1895). His personal contacts were ensured by professors Piotr Stefan Seifmann, and Henryk Kadyi.

Detailed biographical notes of the pioneer Lwów professors, which can be found in the literature (Kadyi, 1895; Millak, 1963; Padura, 2011; Tarczyński, 1990), would not be mimeographed.

Seifmann (born 1823, died 1903) was the first Polish veterinary researcher (Tarczyński, 1990). An alternative, but less appropriate, and less correct variant of his name 'Seifman' can be found both in sources, and literature, and should be rejected. Acting as the first school's headmaster in the years 1881-1894, Seifmann used his experience of managing the Warsaw veterinary school, and the organization of the Veterinary Institute in Kazan (Millak, 1963; Tarczyński, 1990).

Professors Henryk Kadyi [born 1851, died 1912], and Józef Szpilman [born 1855, died 1920, the second director in the years 1894-1897, and rector since 1909], confirm the uniformity of medicine - both human, and veterinary - as one branch of science (Millak, 1963; Tarczyński, 1990). The postulates presented by Szpilman [1886, and 1892], and Kadyi [1890-1891], exerted an influence on the shape of studies not only in the mother institution, but throughout the country. The support of these theses by the academic, and veterinary community of the Austro-Hungarian monarchy allowed the reform of veterinary studies (Sroka, 1999; 2001).

Kadyi, and Szpilman aimed to increase the academic qualifications, and rank of the faculty. These efforts were supported by aristocratic ministers of Polish ori- 
gin, like Julian Dunajewski, or Internal Ministers Agenor Gołuchowski, and Kazimierz Badeni (Sroka, 2001). The Highest Imperial Resolution of December 31 $1^{\text {st }}$, 1896, and ordinances of the Minister of Religions and Education of March 11 ${ }^{\text {th }}$, 1897 and June $11^{\text {th }}, 1901$ were issued. Pursuant to these decisions, the veterinary school in Lwów obtained the status, and name of the Imperial and Royal Veterinary Academy in 1896, and full academic rights in 1909 (Tarczyński, 1990).

\section{Summation}

The great importance of the Lwów faculty for Polish veterinary medicine, as well as for the entire nation, was often emphasized - even before the school's establishment (Bujko, Baran, 2015; Gamota, 2011; Redzik, 2006). It enabled veterinarians to be educated in their mother tongue. $74.8 \%$ and $81 \%$ of the students declared Polish nationality in the periods, respectively, 1881-1894 and 1881-1915 (Kadyi, 1895). Many of the students who were faithful of the Armenian, Uniate, Orthodox, and Protestant churches, as well as Jews, felt Poles. On the other hand, $17 \%$ of the students were members of other Slavic nations ruled by the Habsburgs (Tarczyński, 1990).

Repeated, consistent, and continuous scientific, and political efforts of official, and unofficial nature, were carried on. They aimed at establishing, and developing a veterinary university. Usage of politics as a tool of veterinary science advancement, and national educational growth, resulted in numerous scientific studies, and hundreds of well-educated veterinarians. For many years, Lwów veterinary faculty was the only possible way of education in this discipline in Polish. The discussed university became a model for subsequent scientific, and didactic units in Poland.

Despite the fact that the initial financial, and housing conditions were inconvenient, many prominent activists opting for Lwów veterinary medicine crushed ice on the part of the authorities. Hard political work, and, even harder, scientific work allowed to ensure the development of both veterinary science, and education.

\section{Bibliography}

Allegat (1880), Namiestnictwo Królestwa Galicyi i Lodomerii wraz z Wielkiem Księstwem Krakowskiem: allegat A, plan i kosztorys adaptacji z dnia 11 czerwca 1880 r., L. 4149.

Bujko A., Baran S. (2015), Zarys dziejów „Przeglądu Weterynaryjnego” (historia, tematyka, redaktorzy), http://wmbc.olsztyn.pl/Content/5467/Przegl\%C4\%85d\%20Weterynaryjny\%2015\%20II\%202018. pdf, accessed: 15.09.2019. 
Dekret (1859), C. k. Ministerstwo Stanu: dekret z dnia 14 listopada 1859 r., L. 21440.

Gamota A. (2011), Historia lwowskiej uczelni weterynaryjnej i ocalenie jej zasobów historycznych, [in:] M.Z. Felsmann, J. Szarek, M. Felsmann (eds.), Dawna medycyna i weterynaria: pacjent, Chełmno.

Grodziski S. (1993), Sejm krajowy galicyjski 1861-1914, Warszawa.

Gubernium (1823), C.k. gubernium z dnia 14 marca 1823 r., L. 8630.

Kadyi H. (1895), Rozwój i działalność c. k. Szkoły Weterynaryi we Lwowie od jej założenia w r. 1881 aż do końca roku szkolnego 1893/4 z jedną tablicą, Lwów.

Małecki A. et al. (1896), Miasto Lwów w okresie samorząu 1870-1895, Lwów.

Millak K. (1963), Stownik polskich lekarzy weterynaryjnych biograficzno-bibliograficzny 1394-1918, Warszawa.

Odezwa (1823), Wydział Stanowy Królestwa Galicyi i Lodomerii: odezwa z dnia 3 maja 1823 r., L. 150.

Odezwa (1879), Namiestnictwo Królestwa Galicyi i Lodomerii wraz z Wielkiem Księstwem Krakowskiem: odezwa prezydium z dnia 5 lipca 1879 r., L. 5335.

Pismo (1876a), Wydział Krajowy Królestwa Galicyi i Lodomerii wraz z Wielkiem Księstwem Krakowskiem: pismo z dnia 2 czerwca 1876 r., L. 8630.

Pismo (1876b), Wydział Krajowy Królestwa Galicyi i Lodomerii wraz z Wielkiem Księstwem Krakowskiem: pismo z dnia 29 sierpnia 1876 r., L. 21823.

Padura M.F. (2011), Zasnuwannja cisarsko-koroliwśkoj Weterynarnoj Szkoły u Lwowi. Naukowyj Wisnyk LNUWMBT nr 13.4(50).2.

Redzik A. (2006), Szkic z dziejów szkolnictwa wyższego we Lwowie, Niepodległość i Pamięć, nr 13.3(24).

Relacja (1879), Namiestnictwo Królestwa Galicyi i Lodomerii wraz z Wielkiem Księstwem Krakowskiem: relacja z dnia 21 września 1879 r., L. 7350.

Reskrypt (1881a), C. k. MSW: reskrypt z dnia 21 czerwca 1881, L. 8246.

Reskrypt (1881b), C. k. MSW: reskrypty z dnia 12 lipca i z dnia 22 września 1881 r., L. 14428.

Reskrypt (1876), C. k. Ministerstwo Wyznań i Oświaty: reskrypt z dnia 18 lutego 1876 r., L. 4599.

Seifmann P. (1886a), Dzieje założenia we Lwowie Szkoły Weterynaryi, Przegląd Weterynarski, nr 5.

Seifmann P. (1886b), Dzieje założenia we Lwowie Szkoły Weterynaryi (ciąg dalszy), Przegląd Weterynarski, nr 6.

Seifmann P. (1886c), Dzieje założenia we Lwowie Szkoły Weterynaryi (dokończenie), Przegląd Weterynarski, nr 7.

Seifmann P. (1886d), Zdanie sprawy o Szkole weterynaryi we Lwowie za pięcioletni okres jej istnienia, Lwów.

Sprawozdanie (1879), Namiestnictwo Królestwa Galicyi i Lodomerii wraz z Wielkiem Księstwem Krakowskiem: sprawozdanie z dnia 25 lipca 1879 r., L. 26459.

Sprawozdanie stenograficzne (1874), Sejm Krajowy Królestwa Galicyi i Lodomerii wraz z Wielkiem Księstwem Krakowskiem: sprawozdanie stenograficzne z rozpraw galicyjskiego Sejmu krajowego z dnia 14 października 1874.

Sprawozdanie stenograficzne (1875), Sejm Krajowy Królestwa Galicyi i Lodomerii wraz z Wielkiem Księstwem Krakowskiem: sprawozdanie stenograficzne z rozpraw galicyjskiego Sejmu krajowego z dnia 20 maja 1875.

Sroka S.T. (1999), Nauki weterynaryjne we Lwowie do roku 1945, Rzeszów.

Sroka S.T. (2001), 120 lat uczelni weterynaryjnej we Lwowie, Głos UPWr, nr 96. 
Stanowisko (1876), Sejm Krajowy Królestwa Galicyi i Lodomerii wraz z Wielkiem Księstwem Krakowskiem: stanowisko z dnia 25 kwietnia 1876 r., L. 512.

Tarczyński S. (1990), Zarys historii polskiej weterynarii z podstawami deontologii, Warszawa.

Wróblewski Z. et al. (2012), Geneza powstania lwowskiej szkoły weterynaryjnej - działania administracyjne, Istorija rozwytku weterynarnoj nauky i oswity u Lwowi (1784-1914), LNUWMBT, Lwów. 